\title{
Correlation of Body Mass Index and Kellgren-Lawrence Degrees in Genu Osteoarthritis
}

\author{
Vien Hardiyanti ${ }^{1}$, Mariane Devi ${ }^{1}$, I Made Buddy Setiawan ${ }^{2}$, Herman PL Wungou ${ }^{3}$ \\ ${ }^{\text {ISiloam Hospital Kupang }}$ \\ ${ }^{2}$ Department of Orthopedics, Siloam Hospital Kupang \\ ${ }^{3}$ Department of Radiology, Siloam Hospital Kupang
}

\begin{abstract}
Background: Obesity is a major risk factor for osteoarthritis. Objectives: The aim of this study is to determine the correlation between body mass index with Kellgren-Lawrence degree in genu osteoarthritis patients. Methods: This study used cross-sectional design on 97 participants diagnosed with genu osteoarthritis in Siloam Hospital Kupang in the period January-December 2017. Measurement of height and weight was carried out for the calculation of Body Mass Index. KellgrenLawrence degrees were obtained with x-ray photos. Results: Most patients were women (69 patients, 71.7\%), 50-59 years old (34 patients, 35.1\%), with obesity (61 patients, 62.9\%). Conclusion: There was a significant correlation between BMI and Kellgren-Lawrence degree in genu osteoarthritis ( $\mathrm{p}=$ $0.000)$.
\end{abstract}

Keywords: BMI, Kellgren-Lawrence, obesity, osteoarthritis genu

\begin{abstract}
ABSTRAK
Latar Belakang: Obesitas merupakan faktor risiko terjadinya osteoartritis pada lutut. Tujuan: Tujuan dari penelitian ini adalah untuk menentukan korelasi indeks massa tubuh (IMT) dengan derajat Kellgren-Lawrence pada pasien penderita osteoartritis genu. Metode: Penelitian ini menggunakan metode cross-sectional yang dilakukan pada 97 responden yang didiagnosis dengan osteoartritis lutut di Rumah Sakit Siloam Kupang pada periode Januari-Desember 2017. Derajat Kellgren-Lawrence ditentukan berdasarkan foto x-ray konvensional. Hasil: Penderita osteoartritis terbanyak adalah perempuan (69 pasien, 71,7\%), berusia antara 50-59 tahun (34 pasien, 35,1\%), dan dengan IMT kategori obesitas (61 pasien, 62,9\%). Kesimpulan: Terdapat korelasi signifikan antara IMT dan derajat Kellgren-Lawrence pada penderita osteoartritis genu. $(p=0,000)$.
\end{abstract}

Kata kunci: IMT, Kellgren-Lawrence, obesitas, osteoartritis genu

Received [31 Dec 2019] | Revised [6 Apr 2020] | Accepted [9 Apr 2020]

\section{INTRODUCTION}

Osteoarthritis is one of ten diseases that cause disability in developed countries; half of the world's population aged 65 years or more experience osteoarthritis. ${ }^{[1]}$ Globally, osteoarthritis is experienced by around 240 million of the world's population. It is estimated that $9.6 \%$ of men and $18 \%$ of women over 60 years experience symptomatic osteoarthritis. ${ }^{[2]}$ Most cases are in Northern Europe and Russia with a ratio of more than 400 of 100,000 populations. While in
Asia, mostly are in South Asia with a ratio of 320-340 in 100,000 populations. ${ }^{[3]}$ The prevalence of osteoarthritis in Indonesia reaches $8.1 \%$ of the total population; $80 \%$ will experience limited movement, and $25 \%$ cannot carry out their daily activities. $^{[4,5]}$ The prevalence of genu osteoarthritis reaches $15.5 \%$ in men and $12.7 \%$ in women. ${ }^{[5,6]}$ There have been no studies and definitive data on the incidence of osteoarthritis in East Nusa Tenggara (NTT), even more in Kupang. 
Increased BMI is associated with increased compression and joint pressure when walking. ${ }^{[7]} \mathrm{BMI}$ in both sexes is also associated with an increased incidence of osteoarthritis. ${ }^{[8]}$ A meta-analysis study showed that BMI increase of $5 \mathrm{~kg} / \mathrm{m}^{2}$ was associated with $35 \%$ increased risk of developing genu osteoarthritis. ${ }^{[9]}$ Research in Indonesia showed a significant relationship between body mass index with degree of joint damage in genu osteoarthritis patients. ${ }^{[10]}$

This research was to find a correlation between BMI and Lawrence Kellgren degrees in genu osteoarthritis based on conventional $\mathrm{x}$-ray radiographs in Siloam Hospital Kupang.

\section{METHODS}

A cross-sectional analytical study conducted at Orthopedic Department of Siloam Hospital Kupang in June 2018. The population was 97 subjects diagnosed with bilateral or unilateral genu osteoarthritis based on history, physical examination, and X-ray photos in Siloam Hospital Kupang from 1 January to 31 December 2017. The inclusion criteria were all patients who had been medically diagnosed with genu osteoarthritis based on medical records. Patients with incomplete medical records, osteoarthritis other than knee osteoarthritis, osteoarthritis with history of knee injury, patients with no radiographic evidence, and patients with walking disorders (including stroke, central nervous system disease, and history of head trauma) were excluded.

Measurement of height and weight is carried out with digital scales and stadiometers. Body mass index was obtained by Quetelet index (weight in kilograms divided by the square of height in meters $\left(\mathrm{kg} / \mathrm{m}^{2}\right)$ and classified based on the Asia-Pacific criteria: Underweight if the BMI $<18.5 \mathrm{~kg} / \mathrm{m}^{2}$; Normal if BMI $=18.5-22.9 \mathrm{~kg} / \mathrm{m}^{2}$; Overweight if BMI

\section{$=23-24.9 \quad \mathrm{~kg} / \mathrm{m}^{2}$; Obese if $\quad \mathrm{BMI} \geq 25$ $\mathrm{kg} / \mathrm{m}^{2}$. ${ }^{[1]}$}

Radiological classification is according to Kellgren-Lawrence (KL) grading: KL 1 - no definite narrowing of the joint gap and possibility of osteophytes; KL 2 - osteophytes and possible narrowing of the joint gap; KL 3 multiple osteophytes, narrowing of the joint gap and some sclerosis and possible end-bone deformity; KL 4 - large osteophytes, narrowing of the joint gap, severe sclerosis, and have end-bone deformities. ${ }^{[12]} \mathrm{X}$-ray photos were made with a General Electric X-ray machine.

Data related to gender, age, location of osteoarthritis, and comorbidities were taken from the medical records of Siloam Kupang Hospital. Data were processed with univariate and bivariate analysis using the SPSS program.

\section{RESULTS}

Table 1. Characteristic of Sample

\begin{tabular}{|c|c|c|c|}
\hline & $\mathbf{N}$ & & $\%$ \\
\hline \multicolumn{4}{|l|}{ Sex } \\
\hline Male & 28 & & 28.9 \\
\hline Female & 69 & & 71.1 \\
\hline Age (years) & Male & Female & \\
\hline$<40$ & 0 & 1 & 1.0 \\
\hline $40-49$ & 2 & 9 & 11.3 \\
\hline $50-59$ & 8 & 26 & 35.1 \\
\hline $60-69$ & 10 & 20 & 30.9 \\
\hline $70-79$ & 7 & 12 & 19.6 \\
\hline$>80$ & 1 & 1 & 2.1 \\
\hline BMI $\left(\mathrm{kg} / \mathrm{m}^{2}\right)$ & Male & Female & \\
\hline Normal & 7 & 11 & 18.6 \\
\hline Overweight & 5 & 13 & 18.6 \\
\hline Obese & 16 & 45 & 62.9 \\
\hline KL grading scale & Male & Female & \\
\hline KL1 & 2 & 6 & 8.2 \\
\hline KL2 & 9 & 19 & 28.9 \\
\hline KL3 & 11 & 31 & 43.3 \\
\hline KL4 & 6 & 13 & 19.6 \\
\hline $\begin{array}{l}\text { Location of } \mathrm{OA} \\
\text { genu }\end{array}$ & Male & Female & \\
\hline Dextra & 6 & 22 & 28.9 \\
\hline Sinistra & 7 & 14 & 21.6 \\
\hline Bilateral & 15 & 48 & 49.5 \\
\hline
\end{tabular}

Abbreviations: KL, Kellgren Lawrence; BMI, Body Mass Index; OA, Osteoarthritis 
This study was on 97 participants, 69 were female $(71.1 \%)$, mostly $50-59$ years old (34 patients; $35.1 \%$ ). Most participants have KL3 degree (42-43.3\%). Only 8 people $(8.2 \%)$ were in KL 1 degree (Table $1)$.

Participants with normal BMI mostly experiencing KL 2 degree (8.2\%) as seen in Table 2, participants with overweight were majority had KL 2 degree (9.3\%), and participants with obesity majority had KL 3 degree (30.9\%). Somers'd was run to determine the association BMI and degree of joint damage in osteoarthritis amongst 97 participants. There was a moderate, positive correlation between BMI and degree of joint damage, which was statistically significant. $(r=0.435, \quad p$ value $=0.0000) \quad$ (Table

Table 2. Relationship Between BMI and Kellgren Lawrence Grading Scale of Osteoarthritis of Knee

\begin{tabular}{|c|c|c|c|c|c|c|c|}
\hline \multirow[t]{2}{*}{ BMI } & \multicolumn{4}{|c|}{ Kellgren Lawrence Grading, n (\%) } & \multirow{2}{*}{ Total } & \multirow{2}{*}{$r$} & \multirow{2}{*}{$p$} \\
\hline & KL1 & KL2 & KL3 & KL4 & & & \\
\hline \multirow[t]{2}{*}{ Normal } & 5 & 8 & 5 & 0 & 18 & \multirow[t]{2}{*}{0.435} & \multirow[t]{2}{*}{0.000} \\
\hline & $5.2 \%$ & $8.2 \%$ & $5.2 \%$ & $.0 \%$ & $18.6 \%$ & & \\
\hline \multirow[t]{2}{*}{ Overweight } & 1 & 9 & 7 & 1 & 18 & & \\
\hline & $1.0 \%$ & $9.3 \%$ & $7.2 \%$ & $1.0 \%$ & $18.6 \%$ & & \\
\hline \multirow[t]{2}{*}{ Obese } & 2 & 11 & 30 & 18 & 61 & & \\
\hline & $2.1 \%$ & $11.3 \%$ & $30.9 \%$ & $18.6 \%$ & $62.9 \%$ & & \\
\hline \multirow{2}{*}{ Total } & 8 & 28 & 42 & 19 & 97 & & \\
\hline & $8.2 \%$ & $28.9 \%$ & $43.3 \%$ & $19.6 \%$ & $100.0 \%$ & & \\
\hline
\end{tabular}

Abbreviations: KL, Kellgren Lawrence; BMI, Body Mass Index

\section{DISCUSSION}

The majority of male participants experienced a $3^{\text {rd }}$ degree KellgrenLawrence osteoarthritis damage (11.3\%), while the majority of female participants experienced a $3^{\text {rd }}$ degree KL $(32 \%)$ (Table 1). Similar to the prevalence of osteoarthritis based on radiological examination of the knee joint in Indonesia, which has a prevalence rate of $5 \%$ in men and $12.7 \%$ in women. ${ }^{[6]} \mathrm{A}$ study in Lampung found radiological prevalence of osteoarthritis genu, $15.5 \%$ in men and $12.7 \%$ in women. ${ }^{[13]}$ This can be caused by differences in place, pattern of participant activity, and other external factors. ${ }^{[13]}$

In this study, 50-59 years age group is the largest group with $3^{\text {rd }}$ degree KL classification $(15.5 \%)$ (Table 1). This study proves that as they get older, the greater the prevalence of osteoarthritis (Table 1). A previous study in Nottingham area found $70 \%$ of patients over 65 years of age suffered from osteoarthritis based on radiological findings. ${ }^{[14]}$ The prevalence of genu osteoarthritis in female aged 75 years and over can reach $35 \% .^{[15]}$ In Padang, genu osteoarthritis were mostly found in people aged fifty (22 patients, $91.7 \%) .{ }^{[10]}$

There was a relationship with moderate/moderate relationship between BMI with degree of joint damage based on Kellgren-Lawrence as seen in Table 2. The prevalence of osteoarthritis also increases in patients with metabolic diseases (hypertension, hypercholesterolemia, and blood glucose) and genu osteoarthritis in women, especially in obese women. ${ }^{[15-16]}$ Genu osteoarthritis is more common in obese participants compared to non-obese participants in the elderlies in Laweyan Surakarta. ${ }^{[5]}$ A significant correlation between Body Mass Index and the degree of joint damage in genu osteoarthritis was also found in West Sumatra; $88.9 \%$ of obese patients had a heavier degree of osteoarthritis. ${ }^{[10]} \mathrm{A}$ meta-analysis study showed $35 \%$ increased risk of developing genu 
osteoarthritis with $5 \mathrm{~kg} / \mathrm{m}^{2}$ increase in BMI. ${ }^{[9]}$ Framingham study shows that weight loss can reduce the risk of osteoarthritis in women; a weight loss of $5.1 \mathrm{~kg}$ over 10 years reduced the incidence of symptomatic genu osteoarthritis up to $50 \%$. Weight reduction is associated with a significant reduced risk of osteoarthritis in individuals with high $\mathrm{BMI}$ (BMI $\geq 25$ $\mathrm{kg} / \mathrm{m}^{2}$ ), but not with a BMI $<25 \mathrm{~kg} / \mathrm{m}^{2}$. ${ }^{[17]}$ Reyes showed that, compared to subjects with normal weight, being overweight or obese increased the risk of $\mathrm{OA}$ at all 3 joint sites, especially at the knee. A status of overweight, grade I obesity, and grade II obesity increased the risk of knee OA by a factor of 2-fold, 3.1-fold, and 4.7-fold, respectively. ${ }^{[18]}$

\section{CONCLUSION}

There was a significant correlation between BMI and Kellgren-Lawrence degree in osteoarthritis genu patients at Siloam Hospital Kupang.

\section{ACKNOWLEDGEMENT}

The author would like to thank the Director of Siloam Hospital Kupang, Indonesia, for her generous support.

\section{REFERENCES}

[1] Xing D, Xu Y, Liu QL, Ke Y, Wang $\mathrm{B}, \mathrm{Li} \mathrm{Z}$, et al. Osteoarthritis and allcause mortality in worldwide populations: grading the evidence from a meta-analysis. Sci Rep. 2016;6:3-4. doi: 10.1038/srep24393

[2] Osteoarthritis Research Society International. Osteoarthritis: a serious disease, submitted to the U.S Food and Drug Administration [Internet]. New Jersey: Osteoarthritis Research Society International; 2016 [cited 2019 Jan]. Available from: https://www.oarsi.org/sites/default/fi les/docs/2016/oarsi_white _paper_oa_serious_disease_121416 1.pdf.

[3] El-Tawil S, Arendt E, Parker D. Position statement: the epidemiology, pathogenesis and risk factors of osteoarthritis of the knee. J ISAKOS: Jt Disord Orthop Sport Med. 2016;1(4):219-28. doi: 10.1136/jisakos-2015-000002

[4] World Health Organization. Chronic Rheumatic Conditions [Internet]. Geneva: World Health Organization; c2018 [cited 2018 May 24]. Available from: http://www.who.int/chp/topics/rheu matic/en/.

[5] Nugraha AS, Widyatmoko S, Jatmiko SW. Hubungan obesitas dengan terjadinya osteoartritis lutut pada lansia Kecamatan Laweyan Surakarta. Biomedika. 2015;7(1):17. doi: 10.23917/biomedika.v7i1.1587

[6] Soeroso J, Isbagio $H$, Kalim $H$, Broto R, Pramudiyo R. Osteoarthritis. In: Sudoyo J, Setiyohadi B, Alwi I, Simadibrata M, Stiati S, editors. Buku ajar ilmu penyakit dalam. $4^{\text {th }}$ ed. Jakarta: Pusat Informasi dan Penerbitan Departemen Ilmu Penyakit Dalam FK UI; 2016. p. 1205-11.

[7] Harding GT, Dunbar MJ, HubleyKozey CL, Stanish WD, Wilson JL. Obesity is associated with higher absolute tibiofemoral contact and muscle forces during gait with and without knee osteoarthritis. Clin Biomechanics. 2016;31:79-86. doi: 10.1016/j.clinbiomech.2015.09.017

[8] Sanghi D, Srivastava RN, Singh A, Kumari R, Mishra R, Mishra A. The association of anthropometric measures and osteoarthritis knee in non-obese subjects: a cross sectional study. Clinics. 2011;66(2):275-9. doi: $\quad 10.1590 / S 1807-$ $\underline{59322011000200016}$

[9] Bliddal H, Leeds AR, Christensen R. Osteoarthritis, obesity and weight loss: evidence, hypotheses and 
horizons - a scoping review. Obes Rev an Off J Int Assoc Study Obes. 2014;15(7):578-86. doi: 10.1111/obr.12173

[10] Mutiwara E, Najiman, Afriwardi. Hubungan indeks massa tubuh dengan derajat kerusakan sendi pada pasien osteoartritis lutut di RSUP Dr. M. Djamil Padang. J Kes Andalas. 2016;5(2):376-80. doi: 10.25077/jka.v5i2.525

[11] Kiswatai S, Suntoko B, Sukmaningtyas H. Correlation between osteoarthritis grading in femoropatella joint and patella malalignment with pain and disability using WOMAC score. Indon J Rheumatol. 2016;8:7. doi: 10.37275/ijr.v8i1.6

[12] Hayashi D, Roemer FW, Guermazi A. Imaging for osteoarthritis. Ann Phys Rehabil Med. 2016;59(3):1619. doi: 10.1016/j.rehab.2015.12.003

[13] Arismunandar R. The relations between obesity and osteoarthritis knee in elderly patients. J Majority. 2015;4:112.

[14] Holliday KL, McWilliams DF, Maciewicz RA, Muir KR, Zhang W, Doherty M. Lifetime body mass index, other anthropometric measures of obesity and risk of knee or hip osteoarthritis in the GOAL case-control study. Osteoarthr Cartil. 2011;19(1):37-43. doi: 10.1016/j.joca.2010.10.014

[15] Xie D-X, Wei J, Zeng C, Yang T, Li $\mathrm{H}$, Wang $\mathrm{Y}-\mathrm{L}$, et al. Association between metabolic syndrome and knee osteoarthritis: a cross-sectional study. BMC Musculoskelet Disord. 2017;18(1):533. doi: 10.1186/s12891-017-1890-9

[16] Zheng H, Chen C. Body mass index and risk of knee osteoarthritis: systematic review and meta-analysis of prospective studies. BMJ Open. 2015;5(12):1-7. doi:
[17] Herikurniawan, Isbagio $H$, Soewondo P, Diana N, Setiati S. The correlation between body fat distribution and medial tibiofemoral joint space width in obese knee osteoarthritis patients. Indon $\mathbf{J}$ Rheumatol. 2017;9(1):9. doi: 10.37275/ijr.v9i1.63

[18] Reyes C, Leyland KM, Peat G, Cooper C, Arden NK, PrietoAlhambra D. Association between overweight and obesity and risk of clinically diagnosed knee, hip, and hand osteoarthritis: a populationbased cohort study. Arthritis Rheumatol. 2016;68(8):1869-75. doi: $\underline{10.1002 / a r t .39707}$

$\underline{10.1136 / \mathrm{bmjopen}-2014-007568}$ 